\title{
Productive potential of cassava plants (Manihot esculenta Crantz) propagated by leaf buds
}

\author{
REIZALUAMAR J. NEVES ${ }^{1}$, RAFAEL P. DINIZ ${ }^{1,2}$ and EDER J. DE OLIVEIRA ${ }^{2}$ \\ ${ }^{1}$ Centro de Ciências Agrárias, Ambientais e Biológicas, Universidade Federal do Recôncavo \\ da Bahia, Rua Rui Barbosa, 710, 44380-000 Cruz das Almas, BA, Brazil \\ ${ }^{2}$ Embrapa Mandioca e Fruticultura, Rua da Embrapa, s/n, Caixa Postal 007, 44380-000 Cruz das Almas, BA, Brazil \\ Manuscript received on October 26, 2017; accepted for publication on November 22, 2017
}

\begin{abstract}
New techniques of rapid multiplication of cassava (Manihot esculenta Crantz) have been developed, requiring technical support for large-scale use. This work main to evaluate the agronomic performance of plantlets obtained by leaf buds technique against stem cuttings in the field conditions. The work was conducted using the randomized block design in a factorial scheme with 3 varieties (BRS Kiriris, 98150-06, 9624-09) $\times 4$ origins of the plantlets (conventional - stem cuttings of $20 \mathrm{~cm}$ length, leaf buds of the upper, middle and inferior stem part) $\times 2$ agrochemicals (control and treated). There was a remarkable decrease in some agronomic traits that ranged from $23 \%$ (number of branches) to $62 \%$ (shoot weight) when using leaf buds plantlets. The treatment of plantlets with agrochemicals promoted significant increases in all traits, ranging from $26 \%$ (number of roots per plant) to $46 \%$ (shoot weight). The plantlets originating from leaf buds of the upper and middle parts were able to generate stem-like plants similar to stem-derived ones. Despite its lower agronomic performance under field conditions, multiplication by leaf buds may generate five times the number of propagules in comparison with the conventional multiplication, and therefore it could be a viable alternative for rapid cassava multiplication.
\end{abstract}

Key words: propagation, vigor, field conditions, root production.

\section{INTRODUCTION}

Wide agroecological adaptability makes cassava the third most important source of energy in the tropics (Hasibuan and Nazir 2017). However, some bottlenecks such as a low plant material multiplication rate still remain as a challenge for cassava growers and producers (Ceballos et al. 2015). The conventional method of cassava planting via asexual propagation, coupled with the long

Correspondence to: Eder Jorge de Oliveira

E-mail: eder.oliveira@embrapa.br cycle of the crop, has hampered the development and implementation of crop breeding programs (Bredeson et al. 2016); this is because it takes about five to six years between the parents' hybridization and the initial cycles of evaluation and selection to complete one breeding cycle (Boonchanawiwat et al. 2011, Okogbenin et al. 2012). For growers, the biggest challenge is to produce enough propagating material to replace obsolete varieties with new improved varieties. The FAO report (2013) points out that, in order to obtain gains in the cassava production system, it is necessary to 
reduce the restrictions related to planting material multiplication and distribution of, aiming at the sustainable intensification of crop production. In this sense, some propagation techniques have been used to overcome these problems.

The cassava in vitro micropropagation technique allows the production of a larger number of plants, mainly disease-free in less space, than conventional methods of stem production (Aladele and Kuta 2008). However, some of the limiting factors of this technique are the need for laboratorial infrastructure, skilled and trained labor and above all the higher cost of plant production than conventional propagation systems (Ogero et al. 2010). In contrast, some alternative techniques of rapid multiplication were developed in order to increase the rate of cassava propagation at a lower cost, germinating two or three buds and then cutting shoots. These are subsequently submitted to rooting in water (Rodrigues et al. 2008). However, it is hard work and requires intensive labor for plantlet generation. Remison et al. (2015) pointed out that one way of increasing the availability of large-scale planting material in cassava crops would be to reduce the nodal units of the stake, i.e., by reducing the length of the cassava cuttings.

The cassava stems are formed by nodal units composed of axillary buds, which are responsible for the development of new shoots (Ceballos and De La Cruz 2002). The stems' leaves produce the carbohydrates necessary to maintain the nodal units and influence root growth (Cock 2012). Therefore, the use of the leaf bud cutting technique for cassava propagation becomes feasible, since it allows the multiplication of the planting material from a single leaf and a nodal unit from four or five months of planting (Burgos et al. 2009).

Despite its potential as a new technique for rapid multiplication in cassava, no studies were found in the literature that demonstrated the agronomic performance of the plantlets produced from the leaf bud cutting technique. Conversely, performance of plantlets from micropropagated plant cuttings was superior in number of storage roots and root weight per plant to the conventional stem cuttings cultivated in the field (Acedo and Labana 2008). In other species, such as Olea europaea L., the vegetative and productive performance of micropropagated plants against grafted and ungrafted plants indicated that in vitro propagation may be a powerful and rapid tool in this species, although there are important phenological differences (lower weight and fruit production) attributed to genetic modifications induced by in vitro propagation (Bati et al. 2006).

Regarding conventional cassava propagation under field conditions, Remison et al. (2015) pointed out that sprouting rate and vegetative growth are related to the number of buds in the cuttings, considering their relationship with root and shoot development, although the size of the propagation material did not affect the productivity, dry matter content, root weight and root size. However, knowledge about the performance of cassava plantlets propagated by leaf bud cuttings under field conditions is still scarce, compared to several studies of the effect of different cutting sizes in yield components. Studies on vegetative propagation by leaf buds have mostly been related only up to the rooting stage and have shed little light on plant growth and development under field conditions. The objective of this work was to evaluate the performance in field conditions of the cassava plantlets obtained by the leaf bud cutting technique, considering agronomic traits of productivity and stems quality, in comparison to the conventional method of cassava propagation.

\section{MATERIALS AND METHODS}

\section{PLANTLET PREPARATION}

The experiment was carried out in the experimental area of Embrapa Mandioca and Fruticultura in Cruz das Almas (Bahia, Brazil), located at 1240’19”S, 
3906'22'W, $226 \mathrm{~m}$ altitude. Plantlets of varieties BRS Kiriris and 98150-06 and 9624-09 were obtained using leaf buds. For plantlet formation, the aerial part of the mother plants at 6 months after planting (MAP) were collected and kept in containers with water, for further reduction of leaf blade ( $1 / 3$ of the original size). Then, identification and separation of leaf buds from the different positions of the stem (i.e., upper part - herbaceous, middle part - intermediate, inferior part - lignified) and subsequent "V" cutting using a sterilized scalpel were performed.

The leaf bud cuttings were planted in plastic tubes of $290 \mathrm{~cm}^{3}$ containing vermiculite and washed sand (1:1 ratio) in the upper part of the plastic tube (1/4 of the total volume) and vermiculite, soil and coconut fiber (1:2:1 ratio) along with $15 \mathrm{mg}$ of single superphosphate and $15 \mathrm{mg}$ of ammonium sulfate in the lower part of the tube $(3 / 4$ of the total volume). This division of the substrate is important for plantlet development, once the leaf buds remain in moist and aerated substrate in the initial germination and establishment stage.

The leaf bud cuttings were conditioned in a greenhouse with humidity $(70 \pm 5 \%)$ and temperature $\left(28^{\circ} \mathrm{C} \pm 2^{\circ} \mathrm{C}\right)$ controlled for the development and rooting of the shoots. The plants were kept in a greenhouse for rooting induction until they reached approximately $10 \mathrm{~cm}$ of height, and then the plantlets were kept in 50\% shading for 5 days for later filed transplanting. Plantlets of the three varieties were also produced from $20 \mathrm{~cm}$ cuttings from stems with 10 MAP (conventional multiplication). The cuttings were planted in $1 \mathrm{~kg}$ bags containing the following substrate: vermiculite, soil and coconut fiber in the 1:2:1 ratio, plus $75 \mathrm{mg}$ of single superphosphate and $75 \mathrm{~g}$ of ammonium sulfate for each $\mathrm{kg}$ of substrate. Similarly to the plantlets from leaf buds, the conventional plantlets were kept under a shade of $50 \%$ for root induction for a period of 15 days for later transplant to the field.
The effect of the agrochemicals use (fungicide and insecticides) to control stem- and root rotcausing pathogens was also evaluated, while to control stem- and root rot-causing pathogens was also evaluated, while considering that the stem cuttings and leaf buds were cut with subsequent exposure of the vegetal tissue to the substrate. The treatment consisted of $160 \mathrm{mg}$ of Thiamethoxam as well as $7.6 \mathrm{mg}$ of Mefenoxam, $9.5 \mathrm{mg}$ of Fludioxonil and $57 \mathrm{mg}$ of Thiabendazole; these were all diluted in $100 \mathrm{ml}$ of distilled water. The leaf buds and stem cuttings were submerged in the solution for 3 minutes and were then planted in the plastic tubes and $1 \mathrm{~kg}$ bags, respectively. The control was composed of stem cuttings and leaf buds untreated with agrochemicals.

The experimental area was conventionally prepared with one plowing and two harrows, and then the planting holes were manually opened by hoe at a spacing of $0.80 \mathrm{~m} \times 0.80 \mathrm{~m}$, using the single row system. The plantlets were transplanted to the field 90 days after cutting, and the experiment was installed under a randomized complete block design in a factorial scheme with 3 varieties (BRS Kiriris, 98150-06 and 9624-09) $\times 4$ origin of the plantlets (from stem cuttings and leaf buds from upper, middle and inferior positions of the mother plants $) \times 2$ treatment with agrochemicals (treated and untreated), with two replicates and plots composed of 8 plants. All necessary cultural practices were performed according to Souza et al. (2006). Water supply was carried out via sprinkler irrigation when soil water contents were below to field capacity.

\section{TRAITS EVALUATED}

The evaluations were carried out at 10 MAP plot. Before the roots harvest, the following traits were evaluated: 1) shoot weight per plant (ShoWe); 2) number of branches per plant (NuBra); and 3) height of the stem with suitable planting pattern (SteHe), measured in meters of the ideal stem 
portion for mechanized planting. At the harvest time, the following traits were evaluated: 1) root weight per plant (RoWe); 2) number of roots per plant (NuRo); and 3) dry matter content of the roots (DMC). These were evaluated by sampling roots selected from different plants of the same plot, which were dried in an oven with forced air circulation at $60^{\circ} \mathrm{C}$ until constant weight.

\section{STATISTICAL ANALYSIS}

Before analyzing the traits, we verified the fulfillment of the basic assumptions of the analysis of variance. Then, the analysis of variance was performed in a triple factorial scheme, using the "ea2" function of the easyanova package (Arnhold 2013) implemented in R software (R Development Team 2016). Then, the means were compared by the Tukey test $(\mathrm{p}<0.05)$.

\section{RESULTS}

\section{ANALYSIS OF VARIANCE}

The analysis of variance revealed that the sources of variation varieties, origin of the plantlets and treatment with agrochemicals showed significant differences for all traits except DMC, which showed no significant effect of the treatment with agrochemicals (Table I). In contrast, some interactions were significant, especially for the variety $\times$ origin of the plantlets (ShoWe, SteHe and RoWe), variety $\times$ treatment with agrochemicals (ShoWe and DMC), and origin of plantlets $\times$ treatment with agrochemicals (ShoWe, SteHe and RoWe). For the traits NuBra and NuRo, there was no interaction between any variables, evidencing that the effects can be analyzed separately. The coefficient of variation (CV) estimates presented varied magnitudes, depending on the trait. CV values above $20 \%$ were identified for the ShoWe (30.74\%) and NuBra (22.92\%), while for the SteHe, RoWe, NuRo and DMC traits, the CV values were below $20 \%$ (Table I). In general, the agronomic traits measured in this work suffered great environmental influence (Aina et al. 2007, Akinwale et al. 2010), and therefore higher CV was expected.

There was a consistency in the agronomic performance of the three varieties for all traits, in which the clone 9624-09 presented higher estimates for ShoWe (1.51 kg plant $\left.{ }^{-1}\right)$, NuBra (2.47), SteHe $(0.87 \mathrm{~m})$, RoWe (1.76 kg plant $\left.{ }^{-1}\right)$ and NuRo (4.86) (Table II). For DMC, the clone 98150-06 was more responsive in relation to the other cassava varieties, because it presented $46.17 \%$ of dry matter in the roots. Among the varieties, BRS Kiriris showed low agronomic performance for all traits, except for NuBra and NuRo, for which there was no difference for the clone 98150-06.

Considering the plantlets' origins, there was a marked decrease for ShoWe, RoWe and NuRo traits, i.e., $62 \%, 56 \%$ and $46 \%$, respectively, in the average of the plants from leaf buds against the plants obtained by the conventional propagation method (Table II). On average, plants from 9624 09, 98150-06 and BRS Kiriris presented higher RoWe at $75 \%, 94 \%$ and $111 \%$, respectively, than the plants propagated by leaf buds, within each variety (Figure 1). Reductions of less than 23\% and $37 \%$ were observed for $\mathrm{NuBra}$ and $\mathrm{SteHe}$, respectively. However, the origin of the plantlets showed little influence in the DMC, considering that only plants from leaf buds of the inferior stem position were different from the other treatments. In total, the reduction in the average of the plants derived from leaf buds in comparison with conventional multiplication was $0.5 \%$. There was a tendency toward trait reduction in the leaf budderived plants of the upper to inferior positions of the stems in the mother plants, mainly for NuBra, SteHe, RoWe and NuRo.

The use of agrochemical treatment promoted significant gains in the averages of most of the traits analyzed (Table II). The gains were significant both for shoot (increases of $46 \%, 31 \%$ and $29 \%$ for 
TABLE I

Summary of the analysis of variance of the traits of shoot weight per plant (ShoWe), number of branches per plant (NuBra), height of the stem with suitable planting pattern (SteHe), root weight per plant (RoWe), number of roots per plant (NuRo) and dry matter content of the roots (DMC) in cassava plants propagated by stem cuttings and leaf buds.

\begin{tabular}{|c|c|c|c|c|c|c|c|}
\hline \multirow{2}{*}{ Source of variation } & \multirow{2}{*}{$\mathbf{D F}^{1}$} & \multicolumn{6}{|c|}{ Mean square } \\
\hline & & ShoWe & NuBra & SteHe & RoWe & NuRo & DMC \\
\hline Block & 1 & 0.01 & 0.16 & 0.01 & 0.07 & 0.22 & 1.92 \\
\hline Variety (Var) & 2 & $4.40 * * *$ & $3.63 * * *$ & $1.33 * * *$ & $3.02 * * *$ & $3.74 * * *$ & $73.27 * * *$ \\
\hline Plantlets origin $(\mathrm{OP})$ & 3 & $4.27 * * *$ & $1.55^{* * *}$ & $0.47 * * *$ & $5.14^{* * *}$ & $28.00 * * *$ & $2.74 *$ \\
\hline Treatment with agrochemicals (Treat) & 1 & $1.72 * * *$ & $3.49 * * *$ & $0.33 * * *$ & $2.67 * * *$ & $12.23 * * *$ & 0.02 \\
\hline Var $\times$ OP & 6 & $0.30^{*}$ & 0.37 & $0.05 * * *$ & $0.14^{*}$ & 0.26 & 0.80 \\
\hline Var $\times$ Treat & 2 & $0.32 *$ & 0.23 & 0.00 & 0.04 & 0.47 & $4.73 *$ \\
\hline OP $\times$ Treat & 3 & $0.25^{*}$ & 0.16 & $0.02 *$ & $0.41 * *$ & 0.70 & 1.64 \\
\hline Residue & 23 & 0.09 & 0.20 & 0.01 & 0.05 & 0.39 & 0.92 \\
\hline Coefficient of variation (CV-\%) & & 30.74 & 22.92 & 11.84 & 18.12 & 14.55 & 2.16 \\
\hline
\end{tabular}

$\mathrm{DF}_{1}-$ degree of freedom; $* * * * * *-$ significant at $5 \%, 1 \%$ and $0.1 \%$ of probability by $\mathrm{F}$ test.

TABLE II

Averages of agronomic traits evaluated in plants of the BRS Kiriris, 98150-06 and 9624-09 varieties derivate from stem cuttings and leaf buds from the upper (U), middle (M) or inferior (I) position of the stems from the mother plants, treated or untreated with agrochemicals.

\begin{tabular}{ccccccc}
\hline Variables & $\begin{array}{c}\text { ShoWe } \\
\left(\mathbf{k g ~ p l a n t ~}^{-1}\right)\end{array}$ & NuBra & SteHe (m) & $\begin{array}{c}\text { RoWe } \\
\left(\mathbf{k g} \text { planta }^{-1}\right)\end{array}$ & NuRo & DMC (\%) \\
\hline BRS Kiriris & $0.46 \mathrm{c}$ & $1.52 \mathrm{~b}$ & $0.33 \mathrm{c}$ & $0.89 \mathrm{c}$ & $3.95 \mathrm{~b}$ & $42.05 \mathrm{c}$ \\
$98150-06$ & $1.04 \mathrm{~b}$ & $1.89 \mathrm{~b}$ & $0.79 \mathrm{~b}$ & $1.33 \mathrm{~b}$ & $4.11 \mathrm{~b}$ & $46.17 \mathrm{a}$ \\
$9624-09$ & $1.51 \mathrm{a}$ & $2.47 \mathrm{a}$ & $0.87 \mathrm{a}$ & $1.76 \mathrm{a}$ & $4.86 \mathrm{a}$ & $45.12 \mathrm{~b}$ \\
U & $0.86 \mathrm{~b}$ & $2.11 \mathrm{ab}$ & $0.69 \mathrm{~b}$ & $1.20 \mathrm{~b}$ & $4.04 \mathrm{~b}$ & $44.95 \mathrm{a}$ \\
M & $0.68 \mathrm{~b}$ & $1.79 \mathrm{bc}$ & $0.58 \mathrm{c}$ & $1.02 \mathrm{bc}$ & $3.33 \mathrm{c}$ & $44.42 \mathrm{ab}$ \\
I & $0.59 \mathrm{~b}$ & $1.56 \mathrm{c}$ & $0.47 \mathrm{~d}$ & $0.80 \mathrm{c}$ & $3.31 \mathrm{c}$ & $43.81 \mathrm{~b}$ \\
Stem cuttings & $1.88 \mathrm{a}$ & $2.38 \mathrm{a}$ & $0.93 \mathrm{a}$ & $2.28 \mathrm{a}$ & $6.54 \mathrm{a}$ & $44.61 \mathrm{ab}$ \\
Untreated & $0.81 \mathrm{~b}$ & $1.69 \mathrm{~b}$ & $0.58 \mathrm{~b}$ & $1.09 \mathrm{~b}$ & $3.80 \mathrm{~b}$ & $44.43 \mathrm{a}$ \\
Treated & $1.19 \mathrm{a}$ & $2.23 \mathrm{a}$ & $0.75 \mathrm{a}$ & $1.56 \mathrm{a}$ & $4.81 \mathrm{a}$ & $44.47 \mathrm{a}$ \\
\hline
\end{tabular}

Means followed by the same letters for each variable do not differ according to Tukey's test $(\mathrm{p}<0.05)$. ShoWe - shoot weight per plant; NuBra - number of branches per plant; SteHe - stem height per plant; RoWe - root weight per plant; NuRo - number of roots per plant, and DMC - dry matter content of the roots.

ShoWe, NuBra and SteHe, respectively) and root traits (increases of $43 \%$ and $26 \%$ for RoWe and NuRo, respectively). However, for DMC, there was no influence of the treatment with agrochemicals; the averages were $44.47 \%$ (treated) and $44.43 \%$ (untreated). Therefore, the increase of plant vigor provided by the treatment with agrochemicals did not result in a change in the dry matter content on the roots. It is known that DMC in cassava is influenced mainly by genetic differences (Kundy et al. 2015) and that improvement of cultural practices and the use of hormones or transgenic have few practical results.

\section{EFFECT OF THE CASSAVA VARIETIES ON THE ORIGIN OF PLANTLETS}

Considering the analysis of the traits that showed an interaction between the varieties versus the 

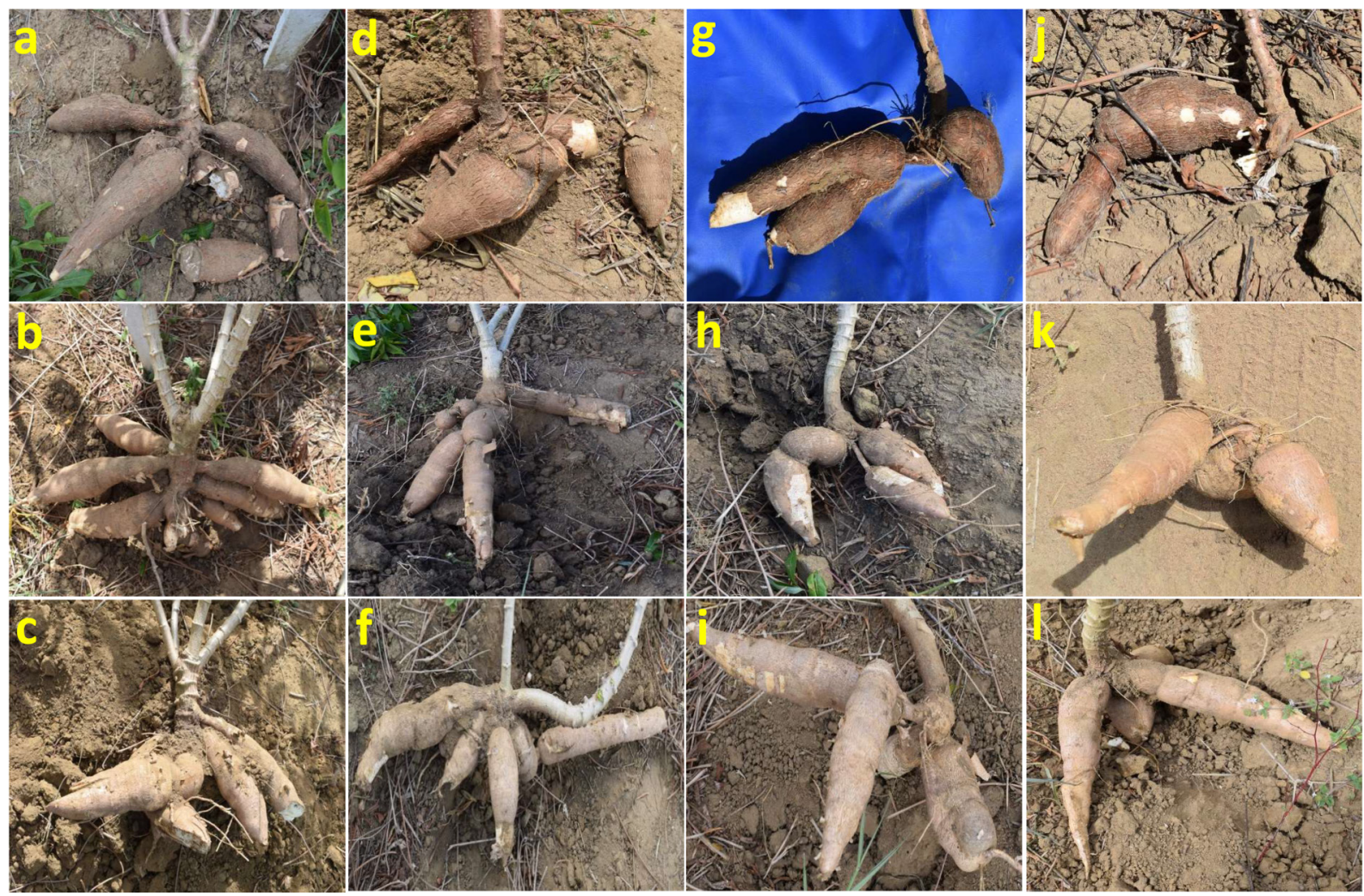

Figure 1 - Overview of the roots from different cassava varieties and origins of the propagation material. (a, b and c): roots from conventional propagation, i.e., stem cuttings with of $20 \mathrm{~cm} ;(\mathbf{d}, \mathbf{e}$ and $\mathbf{f})$ : roots from leaf bud plants from the upper position of the mother plants; ( $\mathbf{g}, \mathbf{h}$ and $\mathbf{i}$ ): roots from leaf buds from the middle position of the mother plants; (j, $\mathbf{k}$ and $\mathbf{~})$ roots from leaf buds from the inferior position of the mother plants; (a, d, g and j): BRS Kiriris variety; (b, e, h and k) 98150-06; and (c, f, i and l) 9624-09.

origin of the plantlets, it was verified that the use of plantlets from leaf buds, regardless of their position on the stem in the mother plant, resulted in the reduction of ShoWe, SteHe and RoWe in comparison with the conventional multiplication that traditionally contains between 5 and 8 buds (Table III). Considering the varietal component, BRS Kiriris was less responsive to leaf bud multiplication, regardless of the position of the leaf buds, for the three agronomic traits (ShoWe, SteHe and RoWe). As an example, when considering the SteHe trait that represents the useful portion of the stem, which has the quality to be propagated by mechanized machines, it was verified that the plants derived from BRS Kiriris leaf buds did not produce stems with suitable standards for commercial use $(\mathrm{SteHe}<0.31 \mathrm{~m})$.
Additionally, when considering only plants derived from leaf buds, it was verified that the superior position of the mother plants was able to generate plants with higher SteHe and RoWe, especially in the more responsive cassava clones, such as 9624-09 and 98150-06 (Table III). In some cases, there was no difference in SteHe in plants derived from leaf buds from the upper position compared to conventional propagation; for instance, in clone 9624-09 (reduction of 7\%). In the case of clone 98150-06, there was difference in the SteHe of the plants derived from these two methods of propagation, but the reduction was not very pronounced $(17 \%)$. Therefore, it is indicated that the leaf buds' technique should be carried out using only leaf buds from the upper position of the 
TABLE III

Decomposition of the interaction between cassava varieties (BRS Kiriris, 98150-06 and 9624-09) and the origin of the plantlets (from stem cuttings or leaf buds extracted from the upper, middle or inferior position of the mother plants) for three agronomic traits.

\begin{tabular}{|c|c|c|c|c|c|}
\hline \multirow[b]{2}{*}{ Trait } & \multirow[b]{2}{*}{ Variety } & \multicolumn{4}{|c|}{ Origin of the plantlets } \\
\hline & & Leaf bud - upper & $\begin{array}{l}\text { Leaf bud - } \\
\text { middle }\end{array}$ & $\begin{array}{l}\text { Leaf bud - } \\
\text { inferior }\end{array}$ & Stem cuttings \\
\hline \multirow{3}{*}{ ShoWe (kg plant $\left.{ }^{-1}\right)$} & BRS Kiriris & $0.34 \mathrm{Bb}$ & $0.26 \mathrm{Bb}$ & $0.21 \mathrm{Bb}$ & $1.03 \mathrm{Ca}$ \\
\hline & 98150-06 & $0.92 \mathrm{Ab}$ & $0.76 \mathrm{ABb}$ & $0.70 \mathrm{ABb}$ & $1.77 \mathrm{Ba}$ \\
\hline & 9624-09 & $1.31 \mathrm{Ab}$ & $1.04 \mathrm{Ab}$ & $0.85 \mathrm{Ab}$ & $2.84 \mathrm{Aa}$ \\
\hline \multirow{3}{*}{ SteHe (m) } & BRS Kiriris & $0.31 \mathrm{Bb}$ & $0.25 \mathrm{Bb}$ & $0.10 \mathrm{Bc}$ & $0.79 \mathrm{Ba}$ \\
\hline & $98150-06$ & $0.82 \mathrm{Ab}$ & $0.70 \mathrm{Abc}$ & $0.67 \mathrm{Ac}$ & $0.99 \mathrm{Aa}$ \\
\hline & 9624-09 & $0.94 \mathrm{Aab}$ & $0.78 \mathrm{Abc}$ & $0.74 \mathrm{Ac}$ & $1.02 \mathrm{Aa}$ \\
\hline \multirow{3}{*}{ RoWe (kg plant $\left.{ }^{-1}\right)$} & BRS Kiriris & $0.76 \mathrm{Cb}$ & $0.78 \mathrm{Bb}$ & $0.42 \mathrm{Bb}$ & $1.61 \mathrm{Ca}$ \\
\hline & $98150-06$ & $1.16 \mathrm{Bb}$ & $1.03 \mathrm{ABb}$ & $0.86 \mathrm{Ab}$ & $2.26 \mathrm{Ba}$ \\
\hline & 9624-09 & $1.69 \mathrm{Ab}$ & $1.27 \mathrm{Abc}$ & $1.13 \mathrm{Ac}$ & $2.97 \mathrm{Aa}$ \\
\hline
\end{tabular}

Means followed by the same letters, lowercase in rows and uppercase in columns, do not differ according to Tukey's test ( $\mathrm{p}<0.05$ ). ShoWe - shoot weight per plant; SteHe - stem height per plant; RoWe - root weight per plant.

stems with the aim of the production of cassavaseeds with better planting quality.

\section{EFFECT OF THE CASSAVA VARIETIES ON TREATMENT WITH AGROCHEMICALS}

Treatment with agrochemicals led to an increase in ShoWe in all cassava varieties, although there was only a significant increase - about $0.70 \mathrm{~kg}$ plant $^{-1}$ - in clone 9624-09 (Table IV). The absence of the agrochemical treatment did not result in differences between clones 98150-06 and 9624-09 for ShoWe (0.93 and $1.16 \mathrm{~kg}$ plant $^{-1}$, respectively), but only in relation to BRS Kiriris $\left(0.36 \mathrm{~kg} \mathrm{plant}^{-1}\right)$. Conversely, when the plantlets were treated with agrochemicals, the three cassava varieties presented differences between them for ShoWe, in which the clones 9624-09, 98150-06 and the BRS Kiriris variety presented $1.86,1.15$ and $0.56 \mathrm{~kg} \mathrm{plant}^{-1}$, respectively.

There were increases for DMC provided by the treatment with agrochemicals in the propagating material in the BRS Kiriris variety only (increase of $1.30 \%$ ). In varietal terms, DMC was similar between clones 98150-06 and 9624-09, but higher than BRS Kiriris (Table IV).

\section{EFFECT OF THE ORIGIN OF THE PLANTLETS ON THE TREATMENT WITH AGROCHEMICALS}

In general, the treatment with agrochemicals in the plantlets originated from the leaf buds of the upper and middle positions and of the stems, which provided an increase for the agronomic traits ShoWe, SteHe and RoWe (Table V). The increases with the use of agrochemicals in ShoWe varied from $42 \%, 21 \%$ and $13 \%$ in the plants propagated by conventional propagation and the leaf buds of the upper and middle positions of the stems, respectively (Table V). For the SteHe trait, the increments varied between $30 \%$ (leaf buds from middle position in the mother plants) to $33 \%$ (leaf buds from upper position in the mother and from conventional propagation). Higher increases were observed for RoWe; i.e., 34\%, 41\% and 57\% in the plants propagated by leaf buds collected from the upper position, the middle position and the conventional propagation, respectively. Plants propagated by leaf buds from the inferior position of the mother plants responded positively to the treatment with agrochemicals, but there was no significant difference to the untreated plantlets from the means test (Table V). 
TABLE IV

Decomposition of the interaction between cassava varieties (BRS Kiriris, 98150-06 and 9624-09) and treatment with agrochemicals, for two agronomic traits.

\begin{tabular}{ccccc}
\hline \multirow{2}{*}{ Trait } & Agrochemical & \multicolumn{3}{c}{ Varieties } \\
\cline { 2 - 4 } & & BRS Kiriris & $\mathbf{9 8 1 5 0 - 0 6}$ & $\mathbf{9 6 2 4 - 0 9}$ \\
\hline \multirow{2}{*}{ ShoWe $\left(\mathrm{kg} \mathrm{plant}^{-1}\right)$} & Untreated & $0.36 \mathrm{Ab}$ & $0.93 \mathrm{Aa}$ & $1.16 \mathrm{Ba}$ \\
& Treated & $0.56 \mathrm{Ac}$ & $1.15 \mathrm{Ab}$ & $1.86 \mathrm{Aa}$ \\
\hline \multirow{2}{*}{ DMC $(\%)$} & Untreated & $41.40 \mathrm{Bb}$ & $46.47 \mathrm{Aa}$ & $45.41 \mathrm{Aa}$ \\
& Treated & $42.70 \mathrm{Ab}$ & $45.88 \mathrm{Aa}$ & $44.83 \mathrm{Aa}$ \\
\hline
\end{tabular}

Means followed by the same letters, lowercase in rows and uppercase in columns, do not differ according to Tukey's test ( $\mathrm{p}<0.05$ ). ShoWe - shoot weight per plant, and DMC - dry matter content of the roots.

TABLE V

Decomposition of the interaction between origin of the plantlets (from stem cuttings or leaf buds extracted from the upper, middle or inferior position of the mother plants) and treatment with agrochemicals, for three agronomic traits.

\begin{tabular}{cccccc}
\hline \multirow{2}{*}{ Trait } & Agrochemical & \multicolumn{3}{c}{ Origin of the plantlets } \\
\cline { 3 - 5 } & & Leaf bud - upper & Leaf bud - middle & Leaf bud - inferior & Stem cuttings \\
\hline \multirow{2}{*}{$\begin{array}{c}\text { ShoWe }(\mathrm{kg} \\
\left.\text { plant }{ }^{-1}\right)\end{array}$} & Untreated & $1.20 \mathrm{Bb}$ & $1.19 \mathrm{Bb}$ & $1.15 \mathrm{Ab}$ & $1.39 \mathrm{Ba}$ \\
\hline \multirow{2}{*}{\begin{tabular}{c} 
SteHe $(\mathrm{m})$ \\
\multirow{2}{*}{$\begin{array}{c}\text { RoWe }(\mathrm{kg} \\
\text { plant }\end{array}$}
\end{tabular}} & Untreated & $1.46 \mathrm{Ab}$ & $1.35 \mathrm{Ab}$ & $1.27 \mathrm{Ab}$ & $1.98 \mathrm{Aa}$ \\
\hline
\end{tabular}

Means followed by the same capital letter in the column and lowercase in the row, for each variable and variety do not differ by Tukey test $(\mathrm{p}<0.05)$. ShoWe - shoot weight per plant; SteHe - stem height per plant; and RoWe - root weight per plant.

Regardless of the treatment, the plants derived from conventional propagation were superior to the plants produced by leaf buds for the three agronomic traits (ShoWe, SteHe and RoWe). However, the treatment with agrochemicals accentuated the superiority of plantlets from the conventional method of propagation. For example, the plantlets from conventional propagation presented higher ShoWe compared to those derived from leaf buds (regardless of its position on the mother plant) by $17 \%$ and $45 \%$, without and with agrochemical treatment, respectively. For the SteHe trait, the superiority of the plants from conventional propagation in relation to those derived from leaf buds was $57 \%$ and $65 \%$, without and with treatment with agrochemicals, respectively. On the other hand, this difference was even more pronounced for RoWe, in which the untreated conventional propagation presented about $105 \%$ more root weight per plant compared to the plants derived from leaf buds. For the treated conventional propagation, this increase was even higher (141\%). Therefore, the agrochemicals promoted greater vigor and plant growth, regardless of the type of plantlets used. However, the most significant effects in the use of these agrochemicals occurred in the roots compared to the shoot traits.

\section{DISCUSSION}

\section{EXPERIMENTAL QUALITY AND EFFECTS OF THE MAIN VARIABLES}

In addition to the material used and depending on the experimental and environmental conditions, there may be important negative influences on the experimental precision (Couto et al. 2013). However, the agronomic traits studied presented, in their majority, the values of the coefficients of 
variation classified as low and medium magnitude (Pimentel-Gomes 2009), indicating adequate reliability of the results. Only the ShoWe and NuBra traits presented $\mathrm{CV} \%$ of high magnitude, but the values were similar to those reported by Burgos et al. (2009) and Viana et al. (2002) for the ShoWe in the cassava. According to Borges et al. (2010), high $\mathrm{CV}$ values are commonly found when the study variable is related to underground structures, which hinders the environmental control.

The three cassava varieties present differences regarding the shoot and root agronomic attributes, which may be due to the genetic background of the material. In addition to differences in the gene pool used in the crosses for the generation of these varieties, BRS Kiriris was selected in the Caatinga and Atlantic Forest regions, while clones 9815006 and 9624-09 were selected in the Recôncavo region of Bahia. This may help explain the better performance of clones 98150-06 and 9624-09 compared to BRS Kiriris, especially for the ShoWe, SteHe, RoWe and DMC traits, considering the greater adaptation of these clones at the evaluation site of these experiments.

Regarding the agronomic performance of the plants from leaf bud multiplication (with only one bud), the plantlets presented less vigor in comparison with the conventional multiplication (stem cuttings with 5 to 8 buds). Other authors evaluated the effects of cutting lengths $(10,15,20,25$ and $30 \mathrm{~cm})$ on root growth and yield in cassava and reported that most of the agronomic attributes reduced significantly as the length of the stem cuttings was reduced (Remison et al. 2015). Bridgemohan and Bridgemohan (2014) evaluated the effect of the number of buds on yield and dry matter accumulation in cassava roots and demonstrated that the initial dry matter content ( 6 to $15 \mathrm{~g}$ ) and the number of buds in the cassava (1 to 3 ) significantly influenced crop growth and development. These authors observed that the propagative material containing three buds presented dry matter content capable of positively influencing yield and final dry matter accumulation in the roots, compared with stem cuttings with only one bud. Another factor that contributes to the better development of plants from larger stem cuttings is that up to 30 days after planting, shoot and root growth in cassava depend on the reserves (nutrients) present in the stem cuttings (Alves 2002).

Another important component to be taken into account in this work was the positive effect of the combination of agrochemicals (Thiamethoxam, Metalaxyl-M, Thiabendazole and Fludioxonil) in the treatment of leaf buds and stem cuttings in cassava, which resulted in significant gains for most agronomic traits evaluated during the harvest of the experiments. Reports on the use of agrochemicals as promoters of development in cassava are scarce. However, the application of rooting and growth promoters in cassava has been reported in the literature, such as in the work of Burgos et al. (2009), which demonstrated that the use of auxins in the treatment of cassava cuttings did not significantly alter the performance and yield of the crop. The variations found were associated with the performance of the cultivars per se in detriment to the treatments with hormones.

As a result of the present work, it has been demonstrated that the treatment of leaf buds or stem cuttings of cassava before planting with various agrochemicals (fungicide and insecticide action) cannot only protect plants from initial pest and disease attacks but promote vigor and greater root and shoot development. These results corroborate the results of other crops, in which the use of certain insecticides promoted not only the protective effect but improved the vigor of the plants depending on the species studied (Horii and Shetty 2007). The benefits of using fungicides and/ or insecticides in the physiological processes of plants growth have been demonstrated in several studies, allowing not only a better defense response (Larsen and Falk 2013) but improving the vigor 
and plant establishment in the field (Abati et al. 2014).

Even with root yield and vegetative growth increase promoted by the use of agrochemicals, there was no proportional and significant increase in dry matter content on the roots. Kundy et al. (2015) reported that DMS is influenced mainly by genetic factors with the control of few genes, and the efforts made by crop breeding can be a more viable alternative to carrying out greater changes in their contents compared with other cultural practices. In addition, alternative methods of rapid cassava propagation tend to prioritize the development of the aerial part rather than root production, which in this process would be a secondary evaluation trait.

CASSAVA VARIETIES HAVE DIFFERENTIAL RESPONSES DEPENDING ON THE ORIGIN OF THE PLANTLETS

Cassava varieties responded differently to the plantlets types, considering the genetic aspects inherent to the varieties in which clones 9624-09 and 98150-06 were more responsive in comparison to BRS Kiriris. In addition, depending on the origin of the plantlets (stem cuttings or leaf buds), the varieties showed different behaviors. For example, for ShoWe, there were differences for the three varieties when comparing the plants derived from stem cuttings, but only the 9624-09 and BRS Kiriris varieties presented differences in the plants from the leaf buds in the middle and inferior position of the mother plants (Table III). According to Hartmann et al. (2011), the nutrient supply present in the stem cuttings influences the development pattern of the plants, thus favoring plants derived from propagating material with more size and, consequently, more nutrients. In contrast, Fogaça et al. (2010) demonstrated that the process of cassava tuberization depends on the interaction of endogenous and environmental factors, with great variation among cultivars. Therefore, it is observed that the differences between the treatments for the characteristics evaluated in this work may have been influenced by the difference in the composition of the nutrients present in the stem cuttings and leaf buds allied to the genetic constitution of the varieties.

The superior agronomic performance of plants derived from stem cuttings compared to plants propagated by leaf buds may be related to the greater availability of nutrients in the former in relation to propagation materials with only one bud (without any reserve on the stems). It is known that during the rooting process, there is a great demand of nutrients to supply all the metabolic and physiological processes necessary for the development of the plant. As there is a greater amount of reserve substances in the stem cuttings, the plants develop faster when compared to plants propagated by leaf buds. Indeed, Yomeni et al. (2012) reported that differences in shoot vigor in cassava plants may affect the nutrient balance of the reserves required for initial plant growth. This can help explain the better performance of plants derived from stem cuttings.

The plants propagated by leaf buds presented different performances under field conditions as a function of the position of the buds in the mother plant. The origin of the stake influences the rooting rate and consequently modifies the plantlets' quality (Bona et al. 2012). In this work, plantlets derived from leaf buds at the upper position of the mother plants presented the highest mean values for ShoWe, SteHe and RoWe, but significant differences were observed only for SteHe in the 98150-06 and 9624-09 clones and for RoWe in the 9624-09 clone. The best performance obtained with the leaf buds from an apical position may be related to the higher activity of meristematic cells present in this region and higher levels of internal hormones and biofactors (Hartmann et al. 2011). The variation in the plants' rooting being dependent on the position of the cuttings in the mother plant has been reported in other species 
(Husen 2004, Hughes and Smith 2014). Zalesny et al. (2003) reported that the rooting of the cuttings is the most important biological requirement for the establishment of the plants with consequent stand maintenance, and therefore, it is necessary to use propagating material that can guarantee a high sprout rate and strong root formation.

\section{CASSAVA VARIETIES CAN PRESENT DIFFERENT} RESPONSES TO THE USE OF AGROCHEMICALS

Naturally, cassava varieties have different characteristics depending on their genetic background, which can result in different responses to external factors, such as the use of agrochemicals. For example, for the ShoWe trait, only clone 962409 presented a significant response to treatment with agrochemicals, while for the DMC trait, only BRS Kiriris presented a positive difference between treated and untreated plants. This effect can be attributed to the fact that the use of agrochemicals can modify certain metabolic pathways, considering that the saved energy that would be otherwise spent on cellular repair as a defense response to a pathogen attack or stress condition can be allocated to the growth and maintenance of plant tissues (Afifi et al. 2014). Some authors have reported that agrochemical responses may vary according to the species (Macedo and Castro 2011) and even among cultivars of the same species (Abati et al. 2014). In species of clonal propagation, such as peach trees, the rooting rate as a function of the concentration of the growth regulator varied among different cultivars (Tsipouridis et al. 2005). Therefore, the differentiated response of cassava cultivars to the use of agrochemicals was not unusual to this type of investigation.

As there were no negative effects of the treatment with agrochemicals in the cassava varieties, new research should be carried out to explore the effect of increasing the dosages of agrochemicals in varieties that present difficulties in the rooting of the cuttings and less initial vigor in crop establishment. In this process, the potentiation of the effect of plant regulators on the treatment of cassava cuttings should be done with the maintenance of the availability of water and nutrients during the beginning of planting (Souza et al. 2010). This is true, especially when considering that the plantlets derived from leaf buds are very sensitive in the initial establishment of the multiplication fields and that planting in dry conditions can result in a failure of this system.

\section{DEPENDING ON THE ORIGIN, THE USE OF \\ AGROCHEMICALS MAY POTENTIATE THE GROWTH OF CASSAVA}

Considering that the use of plant regulators stimulates the development of the root system, to allow the plants to increase the capacity of water and nutrient absorption from the soil, essential for plant establishment (Silva et al. 2014), it was concluded that the agrochemical treatment can increase the yield of commercial cassava plantations for various agronomic attribute. This is true especially in plants derived from stem cuttings and leaf buds from the upper and middle position of the mother plants. This differential response of agrochemical use as a function of the plant material's origin is probably due to the fact that the plantlets derived from leaf buds from the inferior position on the stems are more lignified and lack the necessary cofactors for rooting or lack the presence of compounds that inhibit the root formation necessary for the maintenance and nutrition of these plantlets (Hartmann et al. 2011). In the plantlets grown from leaf buds, there was an improvement in some agronomic performance characteristics when agrochemicals were used (1.15 to $1.27 \mathrm{~kg} \mathrm{plant}^{-1}$ of ShoWe, 0.44 to $0.50 \mathrm{~m}$ of SteHe and 0.71 for $0.89 \mathrm{~kg} \mathrm{plant}^{-1}$ of RoWe, in untreated and treated plantlets with agrochemical), although these differences were not significant by the means test. Therefore, the endogenous levels of phytoregulators and the higher lignification of 
the tissues from the inferior part of the mother plant may have inhibited the effect of the treatment with agrochemicals, considering that the enzyme responsible for lignin synthesis also acts on auxin degradation (Hartmann et al. 2011).

Indole butyric acid is one of the most widely used synthetic auxins in the treatment of cuttings with the goal of stimulating root development and consequently greater plant growth (El-Eslamboly 2014). In cassava, the treatment with agrochemicals promoted an increase in development and plant growth, which were its most evident effects on the stem cuttings of $20 \mathrm{~cm}$. This may be related to the greater contact area of stem cuttings with agrochemicals. This large area means that higher levels of endogenous hormones and cofactors have been produced and have interacted positively with an exogenous treatment, resulting in greater increases in the agronomic traits analyzed at the time of harvesting (Hartmann et al. 2011). The performance of the plantlet formation depends on the position of the plant material, since the root induction is related to the difference in the nutritional status of the mother plant. Saifuddin et al. (2013) studied the effects of the application of plant regulators in different positions on the propagative material in two tree species (Leucaena leucocephala and Peltophorum pterocarpum). They observed positive effects when using stakes of the basal position treated with synthetic auxins. According to the authors, this type of propagative material has greater storage of carbohydrates and organogenic activity compared to the other positions of the cuttings in the branch. In contrast, Ezekiel (2010) pointed out that stakes with greater degrees of liginification require greater dosages of plant regulators to promote the rooting of the cuttings.

In general, there is a great discrepancy about the ideal type of propagation material for optimum large-scale plantlet production in several plant species. This is true, especially when considering that in some of them, the most promising results come from the use of basal and median cuttings (Amri et al. 2010), while others reported better performance with apical cuttings (Wendling et al. 2016). Even in cassava, there are contrasting results depending on the type of material used for the propagation, because in the present work, it was verified that plantlets derived from leaf buds of the upper part of the plant (more herbaceous) tend to result in more vigorous plantlets compared with leaf buds from the inferior part of the mother plant. On the other hand, when the propagation is carried out by stem cuttings, some authors have reported that the use of the inferior portion of the stems in field plantations resulted in a higher root and shoot yield compared to the other parts of the stem (Yomeni et al. 2012).

\section{PERSPECTIVES FOR USE OF LEAF BUDS RAPID MULTIPLICATION IN CASSAVA}

One of the main challenges that hinder the diffusion of new cassava varieties and the expansion of planting for different areas is the low rate of conventional multiplication by stem cuttings, which currently varies between 1:5 and $1: 10$, depending on the variety (Ceballos et al. 2011). Conversely, considering the viability of leaf buds and their sprouting rates, it would be possible to reach an annual multiplicative rate of 1:51 to $1: 72$, depending on the variety and source material (unpublished data). Therefore, the method of propagation by leaf buds is interesting, as it can be used to gain a scale in the production of the basic cassava material. However, compared with the conventional propagation method, the agronomic performance of the plants originating from leaf buds under field conditions, regardless of the leaf buds' position on the stems, was lower for all cassava varieties. Therefore, the process of cassava multiplication by leaf buds should use a different production system from that adopted by the stem cuttings. Furthermore, this technique 
should also not be used for the purpose of serving as propagating material for commercial plantations aimed at root production, considering the lower yield potential compared to the plants derived from stem cuttings. Instead, at least one cycle of stem production should be done, and then the stems could be used in commercial plantations to produce roots.

If we consider the data on the average number of stems per plant and the stem heights useful for commercial plantations obtained in this study, it would be possible to obtain 13.8 and 7.7 stem cuttings per plant ( $16 \mathrm{~cm}$ long) on the plants derivate from stem cuttings and leaf buds (considering only leaf buds from the upper and middle position of the mother plants), respectively. Also, considering a multiplicative rate between 1:7 (stem cuttings) and 1:61 (leaf buds) and a two-year cycle for the delivery of the plant material to farmers (first year for plantlet generation and a second year for field multiplication), the multiplicative rate would be $1: 97$ and 1:472 in the propagation methods by stem cuttings and leaf buds, respectively. Therefore, the efficiency of leaf bud multiplication would be about 5 times higher than propagation by stem cuttings, delivering the same quality of vegetable material to the end-users. In addition, it would still be possible to generate about 17.3 and 35.6 t.ha $^{-1}$ of fresh roots in the propagation methods by leaf buds and stem cuttings, respectively, which could certainly contribute to reducing the cost of stem production and producing a much larger quantity of propagative material.

The results obtained in this study provide important information for the optimization of the production system of cassava propagation material through the use of leaf buds. Despite the lower shoot and root productive potential compared to plants derived from stem cuttings of $20 \mathrm{~cm}$, this study lists important agronomic indicators to be taken into account in the assembly of a new cassava propagation material production system using leaf buds.

\section{ACKNOWLEDGMENTS}

The authors thank the Fundação de Amparo à Pesquisa do Estado da Bahia (FAPESB), Coordenação de Aperfeiçoamento de Pessoal de Nível Superior (CAPES), Conselho Nacional de Desenvolvimento Científico e Tecnológico (CNPq) for the financial assistance and scholarship support. We also thank the Syngenta Foundation for Sustainable Agriculture for additional support.

\section{REFERENCES}

ABATI J, ZUCARELI C, FOLONI JSS, HENNING FA, BRZEZINSKI CR AND HENNING AA. 2014. Treatment with fungicides and insecticides on the physiological quality and health oh wheat seeds. J Seed Sci 36: 392-398.

ACEDO VZ AND LABANA CU. 2008. Rapid propagation of released Philippine cassava varieties through tissue culture. J Root Crops 34: 108-114.

AFIFI M, LEE E, LUKENS L AND SWANTON C. 2014. Thiamethoxam as a seed treatment alters the physiological response of maize (Zea mays) seedlings to neighbouring weeds. Pest Manag Sci 71: 505-514.

AINA OO, DIXON AGO AND AKINRINDE EA. 2007. Genetic variability in cassava as it influences storage root yield in Nigeria. J Biol Sci 7: 765-770.

AKINWALE MG, AKINYELE BO, DIXON AGO AND ODIYI AC. 2010. Genetic variability among forty-three cassava genotypes in three agroecological zones of Nigeria. J Plant Breed Crop Sci 2: 104-109.

ALADELE SE AND KUTA DD. 2008. Environmental and genotypic effects on the growth rate of in vitro cassava plantlet (Manihot esculenta). Afr J Biotechnol 7: 381-385.

ALVES AAC. 2002. Cassava botany and physiology. In: Hillocks RJ, Thresh JM and Bellotti AC (Eds), Cassava: Biology, Production and Utilization, CABI Publishing, p. 67-89.

AMRI E, LYARUU HVM, NYOMORA AS AND KANYEKA ZL. 2010. Vegetative propagation of African Blackwood (Dalbergia melanoxylon Guill. \& Perr.): effects of age of donor plant, IBA treatment and cutting position on rooting ability of stem cuttings. New Forests 39: 183-194.

ARNHOLD E. 2013. Package in the R environment for analysis of variance and complementary analyses. Braz $\mathrm{J}$ Vet Res Anim Sci 50: 488-492. 
BATI CB, GODINO G, MONARDO D AND NUZZO V. 2006. Influence of propagation techniques on growth and yield of olive trees cultivars 'Carolea' and 'Nocellara Etnea'. Sci Hortic 109: 173-182.

BONA CM, BIASETTO IR, MASETTO M, DESCHAMPS C AND BIASI LA. 2012. Influence of cutting type and size on rooting of Lavandula dentata L. Rev Bras Plantas Med 14: 8-11.

BOONCHANAWIWAT A, SRAPHET S, BOONSENG O, LIGHTFOOT DA AND TRIWITAYAKORN K. 2011. QTL underlying plant and first branch height in cassava (Manihot esculenta Crantz). Field Crops Res 121: 343349.

BORGES V, FERREIRA PV, SOARES L, SANTOS GM AND SANTOS AMM. 2010. Seleção de clones de batata-doce pelo procedimento REML/BLUP. Acta Sci Agron 32: 643649.

BREDESON JV, LYONS JB, PROCHNIK SE, WU GA, HÁ CM, EDSINGER-GONZALES E, GRIMWOOD J, SCHMUTZ J, RABBI IY AND EGESI C. 2016. Sequencing wild and cultivated cassava and related species reveals extensive interspecific hybridization and genetic diversity. Nat Biotechnol 34: 562-570.

BRIDGEMOHAN P AND BRIDGEMOHAN RSH. 2014. Effect of initial stem nodal cutting strength on dry matter production and accumulation in cassava. J Plant Breed Crop Sci 6: 67-72.

BURGOS AM, CENÓZ PJ AND PRAUSE J. 2009. Efecto de la aplicación de auxinas sobre el proceso de enraizamiento de estacas de dos cultivares de mandioca (Manihot esculenta Crantz). Rev Cien UDO Agric 9: 539-546.

CEBALLOS H AND DE LA CRUZ G. 2002. Taxonomía y morfología de la yuca. In: Opsina B and Ceballos $\mathrm{H}$ (Eds), La yuca en el tercer milenio. Sistemas modernos de producción, procesamiento, utilización y comercialización, CIAT, p. 17-33.

CEBALLOS H, KAWUKI RS, GRACEN VE, YENCHO GC AND HERSHEY CH. 2015. Conventional breeding, marker-assisted selection, genomic selection and inbreeding in clonally propagated crops: a case study for cassava. Theor Appl Genet 128: 1647-1667.

CEBALLOS H, RAMIREZ J, BELLOTTI AC, JARVIS A AND ALVAREZ E. 2011. Adaptation of cassava to changing climates. In: Yadav SS, Redden RJ, Hatfield JL, Lotze-Campen H and Hall AE (Eds), Crop adaptation to climate change, Wiley-Blackwell, Oxford, UK, p. 411425.

COCK JH. 2012. A basic energy source in the tropics. In: Howeler RH (Ed), The Cassava Handbook. A reference manual based on the Asian regional cassava training course held in Thailand, (CIAT Publication), p. 23-38.
COUTO MF, PETERNELLI LA AND BARBOSA MHP. 2013. Classification of the coefficients of variation for sugarcane crops. Cienc Rural 43: 957-961.

EL-ESLAMBOLY AASA. 2014. Effect of watermelon propagation by cuttings on vegetative growth, yield and fruit quality. Egypt J Agric Res 92: 553-579.

EZEKIEL A. 2010. Viable options and factors in consideration for low cost vegetative propagation of tropical trees. Int $\mathrm{J}$ Botany 6: 187-193.

FAO - FOOD AND AGRICULTURE ORGANIZATION OF THE UNITED NATIONS. 2013. Save and Grow: Cassava. A guide to sustainable production intensification. Rome, 129 p.

FOGAÇA CM, SANT'ANNA-SANTOS BF, CORDEIRO DC, CORREIA TD, FINGER FL, OTONI WC AND CARGNINA. 2010. Microtuberização in vitro de cultivares de mandioca: aspectos morfológicos e anatômicos. Acta Bot Bras 24: 624-630.

HARTMANN HT, KESTER DE, DAVIES JUNIOR FT AND GENEVE RL. 2011. Plant propagation: principles and practices, $8^{\text {th }}$ ed., Englewood Clipps, 915 p.

HASIBUAN S AND NAZIR N. 2017. The development strategy of sustainable bioethanol industry on iconic Sumba island, Eastern Indonesia. Int J Adv Sci Eng Inf Technol 7: 276-283.

HORII PM AND SHETTY K. 2007. Enhancement of seed vigor following insecticide and phenolic elicitor treatment. Bioresour Technol 98: 623-632.

HUGHES MA AND SMITH JA. 2014. Vegetative propagation of putatively laurel wilt-resistant redbay (Persea borbonia). Native Plants J 15: 42-50.

HUSEN A. 2004. Clonal propagation of Dalbergia sissoo Roxb. by softwood nodal cuttings: effects of genotypes, application of IBA and position of cuttings on shoots. Silvae Genet 53: 50-55.

KUNDY AC, MKAMILO GS AND MISANGU RN. 2015. Genetic variability among six traits in twelve cassava (Manihot esculenta Crantz) genotypes in southern Tanzania. J Nat Sci Res 5: 33-38.

LARSEN RJ AND FALK DE. 2013. Effects of a seed treatment with a neonicotinoid insecticide on germination and freezing tolerance of spring wheat seedling. Can J Plant Sci 93: 535-540.

MACEDO WR AND CASTRO PRC. 2011. Thiamethoxam: molecule moderator of growth, metabolism and production of spring wheat. Pestic Biochem Physiol 100: 299-304.

OGERO K, GITONGA NM, OMBORI O AND NGUGI M. 2010. Contribution of Agricultural Sciences towards achieving the Millenium Development Goals. In: Mwangi M (Ed), Cassava production and limitation of propagation through tissue culture. FaCT Publisihing, Nairobi, p. 148155. 
OKOGBENIN E, KAHYA SS AND FREGENE M. 2012. Use of biotechnology tools in cassava breeding. In: Howeler $\mathrm{RH}$ (Ed), The cassava handbook. A reference manual based on the Asian regional cassava training course held in Thailand (CIAT Publication), p. 119-145.

PIMENTEL-GOMES F. 2009. Curso de estatística experimental, $15^{\mathrm{a}}$ ed., Piracicaba: Fealq, $451 \mathrm{p}$.

R DEVELOPMENT CORE TEAM. 2016. R: A language and environment for statistical computing. R Foundation for Statistical Computing, Vienna, Austria. URL https: // www.R-project.org/.

REMISON SU, OMORODION E AND EIFEDYI EK. 2015. A re-examination of the effects of length of stem cuttings on the growth and yield of cassava (Manihot esculenta Crantz). Nigerian Ann Nat Sci 15: 9-13.

RODRIGUES AR, ALVES JMA, UCHÔA SCP, ALBUQUERQUE JAA, RODRIGUES GS AND BARROS MM. 2008. Avaliação da capacidade de enraizamento em água de brotações, ponteiros e estacas herbáceas de clones de mandioca de mesa. Rev Agro@ mb 2: 37-45.

SAIFUDDIN M, NORMANIZA O AND RAHMAN MM. 2013. Influence of different cutting positions and rooting hormones on root initiation and root-soil matrix of two tree species stem cuttings. Int J Agric Biol 15: 427-434.

SILVA JV, MIGLIORANZA É, DE OLIVEIRA EC AND FELTRAN JC. 2014. Mandioca 'IAC 14' tratada com reguladores vegetais e bioestimulante. Rev Raízes Amidos Trop 10: 38-48.

SOUZA LS, FARIAS RN, MATTOS PLP AND FUKUDA WMG. 2006. Aspectos socioeconômicos e agronômicos da mandioca. Cruz das Almas - BA. Embrapa Mandioca e Fruticultura Tropical, $817 \mathrm{p}$.

SOUZA MJLD, VIANA AES, MATSUMOTO SN, VASCONCELOS RCD, SEDIYAMA T AND MORAIS OM. 2010. Características agronômicas da mandioca relacionadas à interação entre irrigação, épocas de colheita e cloreto de mepiquat. Acta Sci Agron 32: 45-53.

TSIPOURIDIS C, THOMIDIS T AND MICHAILIDES Z. 2005. Influence of some external factors on the rooting of GF677, peach and nectarine shoot hardwood cuttings. Aust J Exp Agric 45: 107-113.

VIANA AES, SEDIYAMA T, LOPES SC, CECON PR AND SILVA AA. 2002. Avaliação de métodos de preparo de manivas de mandioca (Manihot esculenta Crantz). Ciênc Agrotec 1383-1390.

WENDLING I, STUEPP CA AND ZUFFELLATO-RIBAS KC. 2016. Araucaria clonal forestry: types of cuttings and mother tree sex in field survival and growth. Rev Cerne 22: $19-26$.

YOMENI MO, AKORODA MO AND DIXON AGO. 2012. Cassava (Manihot esculenta Crantz) stems quality for root production effectiveness. In: Proceedings of the $11^{\text {th }}$ triennial Symposium of the ISTRC-AB held at Memling Hotel: Tropical roots and tuber crops and the challenges of globalization and climate changes, p. 261-269.

ZALESNY RS, HALL RB, BAUER EO AND RIEMENSCHNEIDER DE. 2003. Shoot position affects root initiation and growth of dormant unrooted cuttings of Populus. Silvae Genet 52: 273-279. 